\title{
The effect of parent education on the home food environment for overweight adolescents in West Virginia
}

\author{
Kimberly N. Fisher \\ West Virginia University
}

Follow this and additional works at: https://researchrepository.wvu.edu/etd

\section{Recommended Citation}

Fisher, Kimberly N., "The effect of parent education on the home food environment for overweight adolescents in West Virginia" (2009). Graduate Theses, Dissertations, and Problem Reports. 2757. https://researchrepository.wvu.edu/etd/2757

This Thesis is protected by copyright and/or related rights. It has been brought to you by the The Research Repository @ WVU with permission from the rights-holder(s). You are free to use this Thesis in any way that is permitted by the copyright and related rights legislation that applies to your use. For other uses you must obtain permission from the rights-holder(s) directly, unless additional rights are indicated by a Creative Commons license in the record and/ or on the work itself. This Thesis has been accepted for inclusion in WVU Graduate Theses, Dissertations, and Problem Reports collection by an authorized administrator of The Research Repository @ WVU. For more information, please contact researchrepository@mail.wvu.edu. 
The Effect of Parent Education on the Home Food Environment for Overweight Adolescents in West Virginia

Kimberly N. Fisher

\begin{abstract}
Thesis Submitted to the Davis College of Agriculture, Forestry, and Consumer Sciences at West Virginia University in Partial Fulfillment of the Requirement for the degree of:
\end{abstract}

Master of Science

in

Animal and Nutritional Sciences

Cindy Fitch, Ph.D., R.D., Chair

Elaine Bowen, Ed.D

Janet Tou, Ph.D

Division of Animal and Nutritional Sciences

Morgantown, West Virginia

2009

Keywords: adolescent, obesity, residential camp, parent education, intervention, overweight 


\author{
Abstract \\ Effect of Parent Education Sessions on the Home Environment of Overweight \\ Adolescents in West Virginia \\ Kimberly N. Fisher
}

This study is a pre and post-intervention study examining family involvement and healthy food behaviors prior to and three month post nutrition education. The intervention was conducted as part of a residential summer camp for overweight adolescents in West Virginia. Twenty-one parents were included, one parent per camper. The intervention included nine hours of nutritional instructional time consisting of lectures, PowerPoint presentations, and a grocery store tour. Data were measured to determine occurrence of positive changes within the home environment of these families. Parent education sessions were evaluated. A factor analysis and independent samples t test were used respectively to assess internal consistency and pre and post-intervention changes. Significant positive improvements occurred in the following: nutritious food availability $(p<0.02)$, meal planning $(p<0.02)$, aspects of positive family meals $(p<0.02)$. Parent education sessions as part of a residential summer camp intervention made an impact on overall home environment based on parent perceptions. 


\section{Acknowledgements}

I would like to thank the faculty and staff in the Animal and Nutritional Sciences Department at West Virginia University for this opportunity, for their assistance, and for their continued support. I would like to thank my committee members, Cindy Fitch RD, $\mathrm{PhD}$, Janet Tou RD, PhD, and Elaine Bowen EdD for their availability and guidance.

Specifically, I would like to thank Allison Nichols the Evaluations Specialist at Extension Services for her willingness and selflessness to help with my statistical analyses and also for helping me to understand the data. I would also like to thank the Camp NEW You Advisory board for allowing me to join in the research for this fantastic program they have created. Thank you to the parents of Camp NEW You participants, without them, there would be no project.

Thank you to Elaine Bowen for everything she has done for me. Thanks so much for allowing me join the parent education team. It has been an experience that I will never forget. I loved working on our team! I would also like to thank her for all of the help outside camp. I truly appreciate all she has done for me.

A special thank you to Cindy Fitch RD PhD, my advisor and project chair, who was there to answer questions and help brainstorm when I was unsure of which direction to go. I really appreciate all of the countless hours of advising that started even before I became a student here at West Virginia University. I also appreciate the guidance and help she has given me throughout the duration of this project.

I would like to thank Teresa Duncan MD, my "big sister”, for her input and guidance on this project. I am truly grateful for her time, input and comments. I really appreciate all of her help and guidance over the last several months.

Finally, I would like to thank my mom and dad for all of their support and optimism. They have pushed me to become the best person that I can be and for that I will always be grateful. 


\section{Table of Contents}

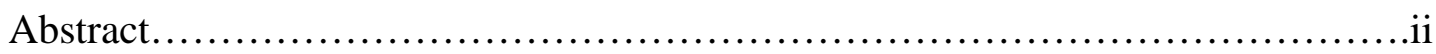

Acknowledgements.......................................................ii

Table of Contents..............................................................

List of Figures............................................................

List of Tables...........................................................

Chapter I: Introduction................................................1

Statement of the Problem..............................................2

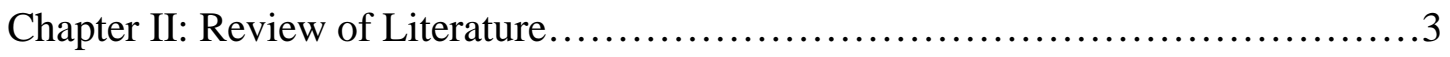

Definition and Measurement of Adolescent Overweight.....................3

Prevalence........................................................

Obesity in West Virginia................................................5

Consequences of Childhood/Adolescent Overweight.......................7

Contributors to the Development of Obesity............................8

1. Community Environment..............................10

2. School Environment....................................11

3. Home Environment...................................12

Prevention of Childhood/ Adolescent Overweight.........................13

Treatment of Childhood/ Adolescent Overweight..........................14

The Parent's Role in Childhood/Adolescent Weight Loss...................16

1. Parent Weight.........................................17

2. Parental Knowledge and Attitudes Toward Nutrition.........17

3. Family Meals.......................................18

Weight Loss/ Maintenance Interventions.................................20

Weight Loss/Maintenance Interventions Including Parents.................21

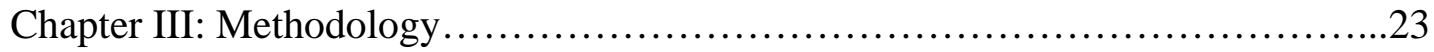


Study Subjects and Procedures.........................................25

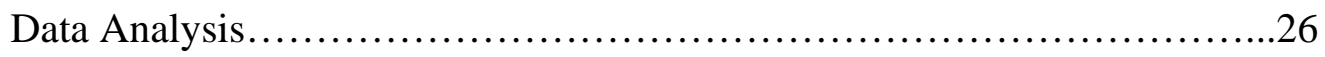

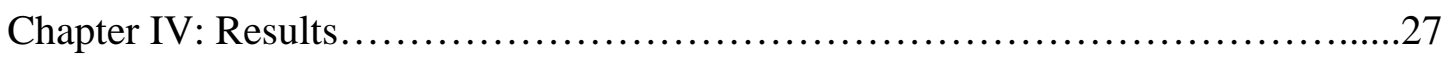

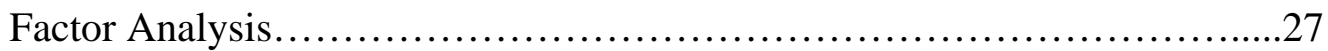

Independent samples t-tests.........................................27

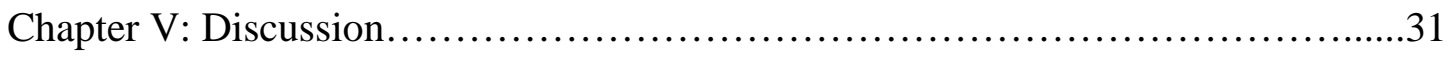

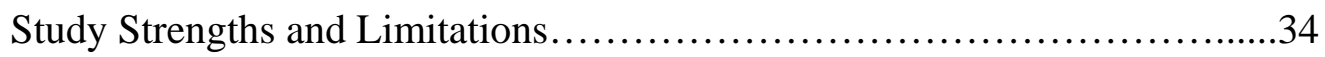

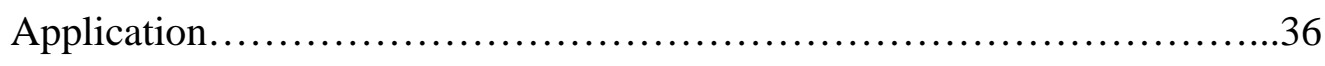

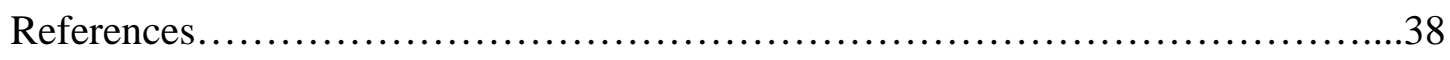

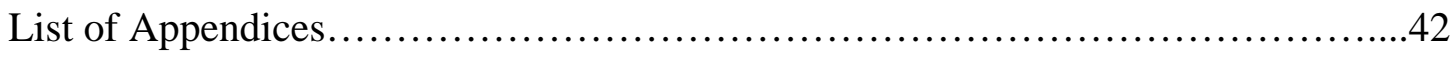

Appendix A: How Healthy Is Your Child's Environment? Survey..............43

Appendix B: Parent Education Sessions Objectives.........................47

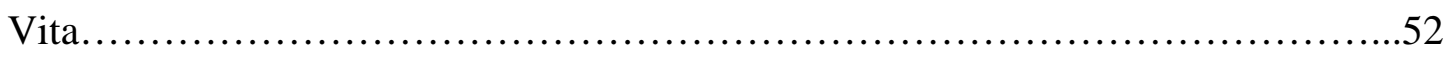




\section{List of Figures}

Chapter I

Figure 1. Prevalence of Overweight among U.S. Children and Adolescents (Aged 2-19 Years) National Health and Nutrition Examination Survey. Figure shows increasing trends of the prevalence of childhood obesity from National Health And Nutrition Examination Survey from 1970 through 2004 4

\section{List of Tables}

Chapter I

Table 1. West Virginia vs. United States (All years) Percentage of Students Who Were Overweight (i.e. At or above the $95^{\text {th }}$ percentile for body mass index, by age and sex) from the Youth Risk Behavior Survey. Table compares prevalence of obesity in West Virginia to that of the United

States. .6

\section{Chapter III}

Table 2. Factor Analysis. Factor Analysis yielded two factors; healthy lifestyle and family involvement. Internal consistency coefficients for each factor were 0.876 and 0.784 respectively and outcome measures were calculated by Cronbach's alpha...... .28

Table 3. Independent Samples T Test, Group Means, Pre \& Post Intervention. Factor: Healthy Lifestyle. T test was performed to determine changes between pre and post intervention. Six questions regarding healthy lifestyles showed significant improvement. $(\mathrm{p}<0.02)$ One question showed significance at $\mathrm{p}<0.05$. Two questions did not reach statistical significant but were considered to be approaching significance. Two questions showed little to no improvement.

Table 4. Independent Samples T Test, Group Means, Pre\& Post Intervention. Factor: Family Involvement. T test was performed to determine changes between pre and post intervention. Two questions dealing with family involvement showed statistical significance at $\mathrm{p}<0.02$ while one showed statistical significance at $\mathrm{p}<$ 0.05 . Three questions showed little to no improvement 


\section{Chapter I: Introduction}

Obesity is defined as an energy imbalance wherein more calories are consumed than expended. Adolescent overweight has become a major health concern with increasing rates over the last three decades (NHANES 2004). There are several health consequences that result from child/adolescent overweight, including increased risk of insulin resistance, hypertension, type 2 diabetes, high total cholesterol levels, sleep apnea, early puberty, and an increased risk for developing obesity in adulthood (American Obesity Association 2008). As a child progresses into adolescence, several studies have shown significant changes both physiologically and psychosocially marking adolescence as a time of great change. Weight management programs focused on behavior modifications dealing with nutrition and physical activity along with weight management intervention programs have been studied previously and will be discussed in more detail later.

Studies have shown that West Virginia’s rate of obesity has been consistently higher than the national rate (American Obesity Association, 2008). Therefore, West Virginia appears to be an ideal location to examine the relationship of parent involvement on weight loss in overweight children. Better understanding of the relationship between parents, the home environment they create, and their children may lead to improved methods to treat and/or prevent obesity. 


\section{Statement of the Problem:}

Adolescent overweight is a rapidly increasing epidemic in West Virginia and the United States. Its resulting consequences include insulin resistance, hypertension, type 2 diabetes, high total cholesterol levels, sleep apnea, early puberty, and an increased obesity in adulthood (American Obesity Association, 2008). Behavior modification studies have been conducted dealing with nutrition and physical activity along with weight management interventions. However, these studies have dealt solely with children and adolescents, which may not be the most effective means of change considering the large role parents play in a child's well-being. There are few studies incorporating parents and children into behavior modification and weight management intervention. Increased parental knowledge toward nutrition has been shown to decrease the incidence of adolescent overweight (Variyam, 2001). It is essential to research strategies for the prevention and/or treatment of child and adolescent overweight because prevalence rates of childhood and adolescent obesity are increasing both nationally and in West Virginia. The home environment plays a pivotal role in the development of dietary habits and behaviors that continue into adulthood (Larson, 2008). The purpose of this study is to determine if parent education sessions are effective in changing the home food environment of overweight adolescents. 


\section{Chapter II: Review of Literature}

\section{Definition and Measurement of Childhood and Adolescent Obesity and Overweight}

Obesity is a condition in which more energy is consumed than expended. Body mass index (BMI) percentile for children and adolescents is calculated for both age and sex, as drastic changes occur by age and sex during childhood and adolescence. BMI can be calculated by the following equation:

$$
\text { BMI = weight }(\text { kilograms }) /[\text { height }(\mathrm{m})]^{2}
$$

Once calculated, the value is plotted on the Center for Disease Control and Prevention's BMI-for-age growth charts, depending on the sex of the child to obtain the percentile ranking. In the United States, percentiles are the most commonly used tool to assess the size and growth patterns for individual children. The percentile shows the position of an individual in relation to children/adolescents of the same age and sex. Children are then classified as underweight, healthy weight, at risk of overweight, and overweight (CDC, 2008). Childhood and adolescent overweight are defined by a BMI between the 85th and 95th percentile. This is considered at risk for overweight, while those at or above the 95th percentile are considered overweight (CDC, 2008).

\section{Prevalence of Adolescent and Childhood Obesity}

The most recent data from the National Health and Nutrition Examination Survey (NHANES 2003-2004) show that the prevalence of overweight has increased from 6.1\% 
(1971-1974) to $17.4 \%$ (2003-2004) for adolescents aged 12-19 years (Figure 1). This is more than triple that of the 5\% target prevalence of the Healthy People 2010 guidelines.

\section{FIGURE 1:}

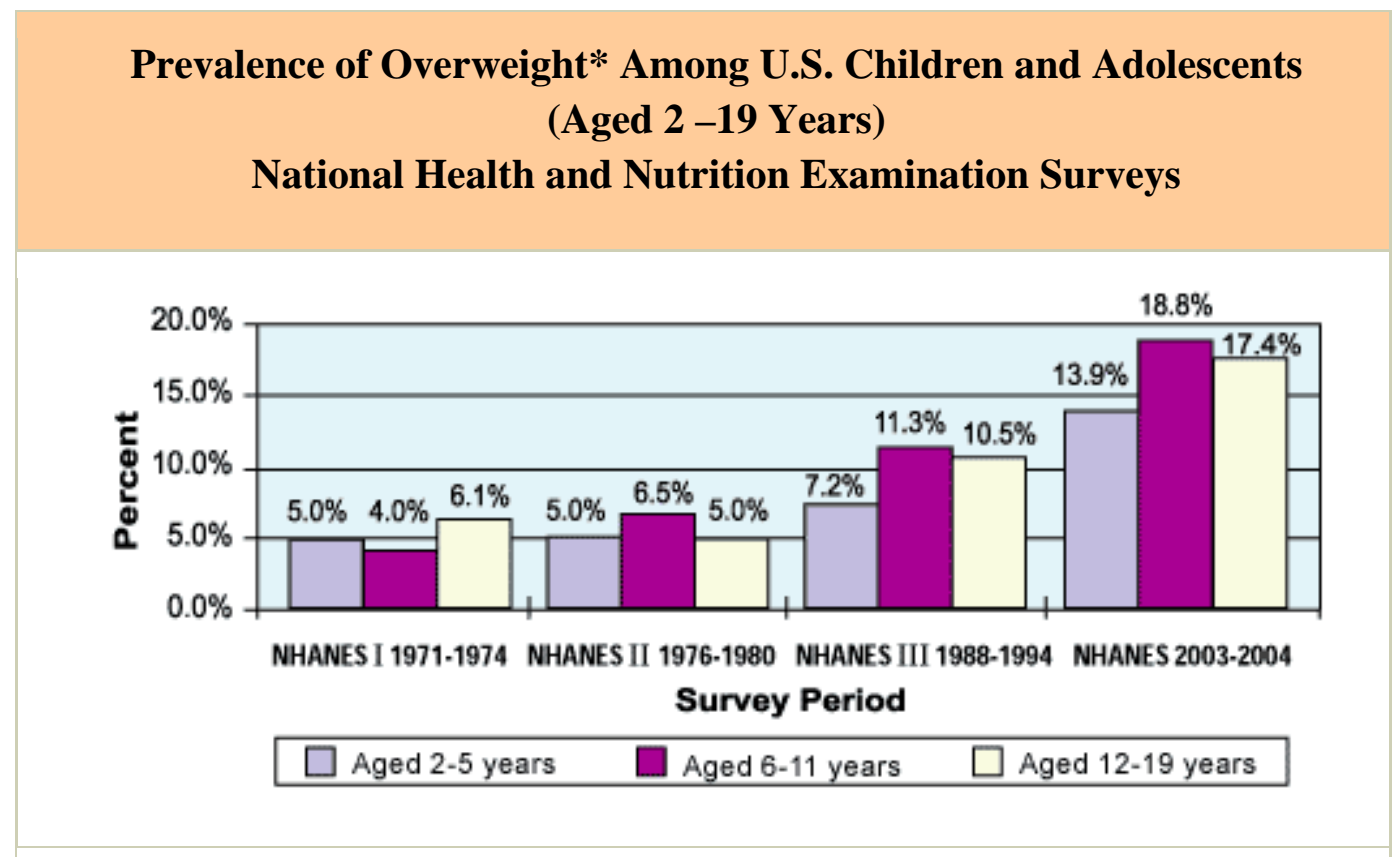

*Sex-and age-specific BMI $\geq$ 95th percentile based on the CDC growth charts.

SOURCE: http://www.cdc.gov/nccdphp/dnpa/obesity/childhood/prevalence.htm 


\section{Obesity in West Virginia}

The most recent data on the prevalence of child overweight in West Virginia come from the 2005 Youth Risk Behavior Survey (Table 1). The survey shows that the prevalence of overweight children and adolescents in West Virginia has increased from $13.3 \%$ in 1999 to $14.5 \%$ in 2005 and is higher than the national percentage of $10.0 \%$. According to the West Virginia Office of Healthy Lifestyles, in a classroom with 30 students, 4.1 of the students were overweight. Among the fifty states, West Virginia is one of the highest ranked in terms of child overweight. West Virginia is also one of the poorest states, which may be a contributing factor. An average West Virginian's annual income for 2005 was less than $\$ 40,000$, compared to the national average of $\$ 46,300$ (US Census Bureau, 2005). West Virginia’s poverty rate was $18 \%$, compared to the national rate of poverty of $13.3 \%$ (USDA). 


\section{Table 1}

\begin{tabular}{|c|c|c|c|c|c|}
\hline \multicolumn{6}{|c|}{$\begin{array}{c}\text { West Virginia vs. United States (All years) } \\
\text { Percentage of Students Who Were Overweight (i.e., At or above the } 95^{\text {th }} \\
\text { percentile for body mass index, by age and sex) } \\
\text { Youth Risk Behavior Survey }\end{array}$} \\
\hline & & Year & 2005 & 2003 & 1999 \\
\hline Sex & Site & & & & \\
\hline Total & \multirow{3}{*}{ WV } & & $14.5( \pm 2.2)$ & $13.7( \pm 3.5)$ & $13.3( \pm 2.0)$ \\
\hline Female & & & $9.8( \pm 2.9)$ & $7.4( \pm 2.1)$ & $8.1( \pm 2.0)$ \\
\hline Male & & & $19.2( \pm 3.2)$ & $19.5( \pm 5.9)$ & $18.3( \pm 3.0)$ \\
\hline Total & \multirow{3}{*}{ US } & & $13.1( \pm 0.9)$ & $12.1( \pm 1.3)$ & $10.7( \pm 1.2)$ \\
\hline Female & & & $10.0( \pm 1.1)$ & $8.3( \pm 1.4)$ & $7.6( \pm 1.1)$ \\
\hline Male & & & $16.0( \pm 1.1)$ & $15.7( \pm 1.3)$ & $13.7( \pm 2.1)$ \\
\hline \multicolumn{6}{|c|}{ Legend: WV= West Virginia } \\
\hline
\end{tabular}

Source: Youth Risk Behavior Survey

Six hundred and seventy ethnically diverse students from grades three to six were recruited from 28 parochial schools in urban and low-income areas. Of the 670, a random sample of 428 was drawn by selecting every third enrolled participant. Based on the analysis of food frequency questionnaires the study showed that children in a low socioeconomic environment were less likely to meet diet requirements and 58\% were also more likely to be overweight when compared to recent NHANES data (Langevin, 2007). Since the prevalence rates of childhood and adolescent obesity are increasing both nationally and in West Virginia, it is essential to research strategies for the prevention and/or treatment of child and adolescent overweight. Increasing trends of overweight and obesity in childhood and adolescence have also been linked to several other medical conditions that arise as a consequence of obesity in adulthood. 


\section{Consequences of Childhood and Adolescent Overweight}

The co-morbidities associated with overweight include metabolic, cardiovascular, and psychosocial disorders. Metabolic disorders in overweight adolescents include type 2 diabetes mellitus and the metabolic syndrome. Previously, type 2 diabetes was considered a disease of adults. It is now occurring in children with a BMI at and above the $85^{\text {th }}$ percentile (Daniels et al, 2005). According to NHANES III, the incidence of type 2 diabetes has more than doubled that of type 1 diabetes (Daniels et al., 2005). In adults, type 2 diabetes is considered as a major risk factor for coronary artery disease by the National Cholesterol Education Program. However, it is unknown whether children face the same risk factor as adults.

Cardiovascular disease has been shown to increase mortality in individuals since 1956 (Heady et al, 1956). Both the Muscatine study and the Bogalusa study showed that being overweight during adolescence can cause several of the risk factors of cardiovascular diseases, including atherogenic dyslipidemia, hypertension, left ventricular hypertrophy, obstructive sleep apnea and atherosclerosis (Daniels et al., 2005). In the Bogalusa study, a higher BMI was associated with more widespread fatty streaks in the arteries, which are typical in the early development of atherosclerosis (Daniels et al., 2005). Left ventricular hypertrophy has also been related to overweight in children. This condition is a concern because increased left ventricular mass is associated with coronary heart disease, stroke and sudden death in adults. Lean body mass, fat mass, and systolic blood pressure were independently associated with left ventricular hypertrophy in children and adolescents (Daniels et al., 1995). 
Metabolic syndrome is defined by the National Heart Lung and Blood Institute as a group of risk factors associated with overweight and obesity that increase the risk for cardiovascular disease and other health problems. There are five risk factors for metabolic syndrome. These include abdominal obesity (having an apple shape), increased triglyceride levels, low high-density lipoprotein cholesterol levels, high blood pressure, and high blood glucose. An individual is diagnosed with metabolic syndrome if three or more of these risk factors are present. A 2004 study found that each half-unit increase in BMI was associated with an approximately 50\% increased risk of metabolic syndrome in children and adolescents (Daniels et al., 2005).

In addition to the physiological effect, the psychological effects of being overweight in children and adolescents should be considered. The most studied psychosocial aspects of child and adolescent overweight is depression. Goodman et al. (2002) found that in 9374 adolescents between $7^{\text {th }}$ and $12^{\text {th }}$ grade levels, a larger BMI was related to depression at one year follow-up. The children with the highest BMI had the highest depression score (Goodman et al., 2002). Overweight children have also been reported to have fewer friends and to be more isolated. This may be associated with psychopathological difficulties (Daniels et al., 2005). Another mediator of psychosocial distress associated with being overweight may arise from other children’s teasing. Eisenberg et al (2003) showed that teasing overweight adolescents is associated with increased numbers of suicidal attempts. Based on these consequences, researching the probable contributors to obesity may prove to be beneficial in the development of new methods of prevention and treatment for child and adolescent overweight.

\section{Contributors to the Development of Obesity}


Genetic, behavioral, and environmental factors are all contributing factors to the development of obesity. Genetic factors may include imbalances in peptide hormones that control the feedback regulation of energy balance. A major peptide hormone, leptin has been related to obesity. Genetic factors appear to increase susceptibility to developing obesity, but are unlikely to be solely responsible for the dramatic increase in prevalence over the last several years (The Obesity Society, 2008). Rather, it is combined with behavioral and environmental factors. Farooqi et al. (1999) showed that the absence of leptin leads to extreme obesity and that supplementation of leptin in congenitally deficient children reduced food intake and body weight. An animal study, McMinn et al. (2000) showed that when a genetic interruption occurs in the mechanism converting the hormone cortisol to its inactive form, cortisone, mice will develop visceral obesity. It is believed this is due to interference in signaling in the hindbrain and mid-brain which are responsible for sending signals for food seeking.

Behavioral factors that potentially contribute to the development of obesity include excessive energy intake, sedentary activity, and lack of physical activity. Several studies have shown that increased availability of high energy, low cost foods and also increased portion sizes have been associated with higher energy intakes (Golan et al., 2004). Another behavioral factor contributing to weight gain is the increase in sedentary activity such as television viewing time and computer use. In a longitudinal study of 106 children, the mean skinfold thickness of children who watched 3.0 hours or more of television each day were 1.5 times greater $(\mathrm{p}=0.007)$ than those who watched less than1.75 hours each day (Golan et al., 2004). However, the effect of television viewing and computer games on weight gain was not associated to physical activity (Sallis et al., 
2000). Television may provide a stimulus for high consumption of unhealthy snacks, thereby leading to overweight (Golan et al., 2004). Television also provides a medium for the advertising industry to reach children, which may contribute to increases in unhealthy snacking. Also, television exposes children to the media's perception of the way one should appear, thin. In a meta-analysis, Groesz et al. (2002) evaluated the manipulation of the thin beauty ideal in 25 studies and found that body image was more negative after viewing images of thin than average-sized models, or inanimate objects (Groesz et al, 2002).

Environmental factors that may affect the development of childhood and adolescent overweight include: 1) community, 2) schools, and 3) the home. According to the Institute of Medicine, these may all influence a child's behaviors in relation to food intake and physical activity.

1) Community Environment. A community plays a role in the development of a child's behaviors by providing access to food and locations for physical activity. One notable community-based intervention aimed at improving diet and physical activity behaviors is the Minnesota Heart Health (MHH) Program. The MHH program began in 1983 with $6^{\text {th }}$ graders from two communities that were revisited annually for seven years. During these visits, behavior measurements were conducted by self-reports dealing with nutrition knowledge and preferences for certain foods. Females showed significantly higher positive responses to the self-report than males after the follow-up period and males indicated higher nutrition knowledge (Kelder et al., 1995). 
2) School Environment. School-based interventions play a role in child behaviors by influencing a child's dietary habits and participation in physical activity. One notable school-based intervention is known as the Child and Adolescent Trial for Cardiovascular Health (CATCH). Conducted between 1991 and 1998, CATCH was designed to reduce cardiovascular risk factors in children (Hoelscher et al., 2004). Fifty-six schools began with the implementation of the CATCH program between 1991 and 1994. These schools were given education materials, training, and support visits from research staff and became known as the formal intervention group. There were three main components to the CATCH program; CATCH PE, Eat Smart, and a classroom curriculum. The goals of CATCH PE were to engage student in moderate to vigorous physical activity for $40 \%$ of their physical education class period. Eat Smart is a program designed to decrease fat content in school meals. The class curriculum utilized CATCH lesions, and activities in the classroom. At the end of the main trial, 20 randomly chosen schools were chosen as the former comparison group and received materials to implement CATCH, but only received a one-day in-service training for the program. The maintenance of CATCH was measured after 5 years post intervention by changes in former intervention and by comparison of the former control schools. Results from CATCH show that after three years, dietary fat intakes in participating schools were significantly lower than schools unexposed to CATCH (Hoelscher et al., 2004). Results from CATCH PE were mearsured by PE School Staff Questionnaires. Eat Smart results were measured by recipe and nutrient analysis and the class curriculum was measured by classroom teaching staff questionnaires. Percent of total energy from carbohydrates were also higher among CATCH schools than the control. CATCH findings show that changes toward school 
environments that support healthful behaviors can be maintained over time thus, further reiterating the role a school plays in a child's life.

3) Home Environment. The home environment influences dietary behaviors by providing the food and influencing the food attitudes, food preferences, and values. The American family has undergone changes in family structure and maternal employment. In 1960, only $9 \%$ of children lived in single-parent households compared to $27 \%$ in 1998 (Story et al., 2002). Also, maternal employment rates have increased, creating a major time constraint when dealing with meal preparation. In 1950, 29\% of the workforce was women. In, 1998, females made up 60\% of the workforce (Story et al., 2002). This increase in maternal employment along with the number of children living in single parent household may possibly be linked to the changes in diet behaviors and quality over the last several decades that have lead to the increased prevalence of childhood/adolescent obesity.

In a 2008 study by Larson et al., researchers examined potential correlates of intake including socio-environmental factors. Data were used from Project EAT (Eating among Teens) and consisted of 1495 young adults completing Project EAT surveys at baseline and follow-up. Associations with fruit and vegetable intake was assessed by the Youth and Adolescent Food Frequency Questionnaire and examined within each gender using the social cognitive theory. Fruit and vegetable availability in the home, familymeal frequency, and parental support for healthy eating at baseline were all positively associated with the follow-up for fruit and vegetable intake levels among both genders. However, the home availability of unhealthy foods in the home was inversely associated with follow-up fruit and vegetable intakes. Understanding the environmental factors 
contributing to the development of overweight/obesity including intake are critical to identify ways to modify, prevent and treat obesity.

\section{Prevention of Child/Adolescent Overweight}

The consequences of childhood/adolescent overweight have been mentioned previously and it should be noted that the risk of these consequences may be reduced by decreasing body fat among overweight individuals (Daniels et al., 2005).

Prevention programs should be based on theory, ranging from addressing social and community changes, to those dealing with home environments including familial models (Daniels et al., 2005). Interventions should be designed about a specific target audience. The best way to engage this audience should also be addressed. By identifying specific issues and factors the probability increases that the audience pays attention, participates in, and becomes motivated by the impending change (Daniels et al., 2005). There are two levels of prevention, primary and secondary. Primary prevention is directed towards preventing children and adolescents at-risk of overweight from advancing to the overweight category. Secondary prevention is the treatment of overweight children in order to reduce the aforementioned medical consequences. Prevention of obesity includes both individualized and population-based approaches.

Population-based approaches generally focus on environmental and policy changes with the ability to reach the broadest and the least advantaged subjects (Daniels et al., 2005). Individualized approaches are more familiar to health professionals and tend to occur in health care facilities and these should be involved in conjunction with community resources (Society for Adolescent Medicine, 2006). Before implementing a 
weight loss prevention program, it is also important to assess the children and adolescents readiness to make changes. Treatments to prevent overweight should consider the adolescent's sensitivity to weight related issues to make sure there are no adverse effects dealing with body image or dissatisfaction and/or unhealthy food-restricting behaviors (Society for Adolescent Medicine, 2006). Initially, treatment is delivered in a medical setting, but then becomes dependent upon families, schools, and communities ensure adherence. Health care providers generally encourage parents to observe their home environment to determine which changes can be made to promote healthy eating and physical activity (Society for Adolescent Medicine, 2006). Research on preventive measure is essential to slow the increasing rates of development of child and adolescent overweight. If preventative measures are not enough, there are many treatment options for children and adolescents that are overweight or obese.

\section{Treatment of Child/Adolescent Overweight}

Approaches in the treatment of child/adolescent overweight are very similar to that of adults including dietary changes and increasing amounts of physical activity. Guidelines for treating overweight children are based on age, degree of overweight, and presence of associated co-morbidities (Daniels et al., 2005). Nutritional goals set by Healthy People 2010 Objectives recommend that Americans follow the Dietary Guidelines for Americans. These guidelines recommend consuming three to five servings from various vegetables and vegetable juices and two to four servings of fruits and fruit juices, depending on one's calorie needs. It is also recommended that Americans consume six to eleven servings of grain products each day. Healthy People 2010 aims to 
increase the proportion of persons over two years of age who consume no more than 30 percent of calories from total fat (USDHHS, 2009).

In managing the diets of adolescents, a diet with adequate maintenance of health and growth should be given. Recommended Dietary Reference Intakes, for 4-18 year old are $25 \%-35 \%$ of total daily calories from fat, $45 \%$ and $65 \%$ of total daily calories from carbohydrates, and $10 \%$ to $30 \%$ of total daily calories from protein (Panel on Macronutrients, 2002). Additional recommendations from the panel include decreasing the amount of saturated fat in the diet, increasing the consumption of fruits and vegetables, adequate amounts of complex carbohydrates and fiber, and decreasing salt and sugar intake (Williams et al., 2002). In addition, dietary approaches should include balancing, variety, and adequate intakes to enhance modifications. Also, appropriate food portions should be incorporated into treatment to help ensure adequate energy intake and encourage nutritional education (Daniels et al., 2005). Counseling and dietary recommendations should be made, but family's culture, living situation, and socioeconomic status should also be considered.

Another area of treatment for child and adolescent overweight is physical activity. The most successful overweight treatment programs incorporate regular physical activity (Barlow et al., 1998). Current recommendations for physical activity include 60 minutes of regular exercise each day (US DHHS, 2009). It is essential that activities are ageappropriate and enjoyable to ensure adherence to physical activity since children/adolescents typically will not exercise specifically to lose weight (Daniels et al., 2005). In addition to adding physical activity to the family environment, parents may also 
play a role by restricting sedentary activity to less than two hours each day to promote children to engage in other activities (Fletcher et al., 1996).

The research area of diet modification and physical activity in the prevention and treatment of child/adolescent overweight is crucial to determine an optimal diet and physical activity regimen for overweight children and adolescents that will ensure the most beneficial effects. As mentioned previously when determining options for prevention and treatment, a child and adolescent's family or caregiver must be involved.

\section{The Parent's Role in Children/Adolescent Weight Loss}

A parent's role in the prevention and treatment of child and adolescent overweight is critical. Although a parent cannot make all decisions that adolescents face, parents create the environment in which adolescents learn to make their own decisions. The home is considered the environment in which a child is raised and is essential to a child's development of dietary and physical activity behaviors along with psychosocial aspects of development (Visser, 2005). Not only do they influence eating behavior, but parents control foods coming into and leaving the house. There are several factors that influence the home environment such as: 1) parent's weight, 2) parent knowledge and attitudes toward nutrition and physical activity, and 3) family mealtimes. These areas should be thoroughly examined in order to provide optimal prevention and treatment of overweight and obesity in child and adolescent. 


\section{1) Parental Weight}

Parental obesity has been strongly associated with the development of overweight in childhood and/or adolescence. Whitaker et al. (1997) found that parental obesity at minimum doubles the risk for adult obesity among children with or without the presence of childhood obesity. Whitaker et al. (1997) also hypothesized that obesity in at least one parent may arise partially from environmental factors in families. Crossman et al. (2006) utilized data from the United States National Longitudinal Study of Adolescent Health and arrived at the same conclusion; parent overweight is linked to overweight in adolescents. Maternal obesity is also a well-established predictor of excess weight in children. Therefore, it is essential to assess parental weight status, to determine whether the home environment plays a role in an adolescent's development of obesity.

\section{2) Parental Knowledge and Attitudes towards Nutrition}

The extent of a parent's knowledge of nutrition and physical activity affects a child's weight. Most studies show that as parental education level increases, the prevalence of overweight children decreases. Results from the 1989-91 Diet and Health Knowledge Survey revealed that the prevalence of overweight decrease in those with greater parental knowledge of nutrition (Variyam, 2001). For example Variyam also found that the prevalence of obesity was $34 \%$ in children whose parents were unaware of health implications that dealt with a diet lacking only in fiber.

Parental attitudes concerning nutrition also impact a child's weight. Most often a child's satisfaction with their bodies is dependent upon their mother's body satisfaction (Evans et al., 1995). A study by Messina et al (2002) reported that a mother's unhealthful 
nutrition attitudes may lead to elevated levels of total cholesterol and low-density lipoprotein (LDL) cholesterol, which is a risk factor for coronary heart disease among daughters at an older age of approximately 11years. The results from this study indicate the importance of assessing parental nutrition knowledge and attitudes when forming intervention programs for overweight children.

\section{3) Family Meals}

Approximately two-thirds of the foods children eat come from the home (Rosenkranz et al, 2008). Family meals are highly promoted, mainly because of the positive effects they have on dietary intake in children. It is believed that family meals have such a positive effect because parents are better able to implement healthier eating habits. Families have the opportunity to influence eating behaviors and attitudes toward food. Family meals have also been associated with increased intake of fruit and vegetables and decreased soft drink consumption (Rhee, 2008). Regular family meals were associated with a lower prevalence of child overweight (Sen, 2006; Taveras et al., 2005; Rhee, 2008). Sen drew data from the National Longitudinal Survey of Youth, 1997. This survey consisted of 6748 participants aged 12-16 as of December 31, 1996. Survey questions focused on the household environment in a typical week. A little more than $8 \%$ reported never having dinner with family in a typical week. Forty-two percent reported dinner with their family everyday in a typical week. The mean BMI was higher among those reporting a frequency of family dinner of zero although poverty was also higher and maternal education was lower in this group than in any other (Sen, 2006) Taveras et al drew data from the ongoing Growing Up Today Study (1996-1998) consisting of 16,882 children who are offspring of participants of the Nurse's Health 
Study II, which was designed to assess dietary intake, physical activity, and inactivity of adolescents. After excluding subjects due to medical conditions affecting growth and those reporting binging and purging behavior in 1996, the final sample size included 7784 boys and 6647 girls. The questionnaire used asked the question,” How often do you sit down with other members of your family to eat dinner or supper?” (Taveras, 2005) Responses included “never, some days, most days, and every day.” At baseline 17.4\% of girls and $15.3 \%$ of boys ate dinner with their families "never or some days," $39.7 \%$ of girls and $40.1 \%$ ate dinner with families on “most days", and $42.8 \%$ of girls and $44.6 \%$ of boys ate family dinner every day (Taveras, 2005). At baseline overweight prevalence was 19.4\% in girls and $24.6 \%$ in boys who had dinner with their families "never or some days," $16.6 \%$ in girls and $23.3 \%$ in boys reporting dinner on "most days," and $16.7 \%$ in girls and $22.7 \%$ in boys whose frequency of family dinner was “every day” (Taveras, 2005). Although not statistically significant, the trends observed from data analyzed show that children eating dinner with other members of their family at least most days of the week were less likely to be overweight at baseline.

Family meals during adolescence were associated with higher diet quality and healthful meal patterns during young adulthood (Larson et al., 2007). An increased frequency of family meals predicted higher intakes of fruits and vegetables, more breakfast meals, and decreases in the amounts of soft drink consumption during adulthood (Larson, 2008). In a 2004 study, data were drawn from 4,746 middle and high school students (aged11-18) surveyed during Project EAT. The frequency of family meals was determined by asking how many times in the past seven days did all or most of the family eat a meal together. Girls participating in the study who reported more 
frequent family meals also reported less substance use (tobacco, alcohol, and marijuana), higher grade point averages, fewer depressive symptoms, and decreased risk of suicide attempts (Eisenberg et al., 2004).

Although several studies show a positive effect of eating meals as a family, the National Longitudinal Survey of Youth (1997) showed that these effects may vary by ethnic groups due to cultural differences in family mealtimes and food choices (Sen, 2006). Therefore, evaluation of the family meal environment may provide clues to assist researchers in determining what truly causes the family meal to be so influential in a child's life. Boutelle and colleagues (2003) evaluated the family meal environment by addressing six components including 1) the frequency of dinner meals together, watching television, and arguments during dinner; 2) rules about mealtime behavior; 3) barriers to eating dinner together; 4) planning meals; 5) pleasantness of the dinner environment; and 6) satisfaction with the frequency of dinner meals together (Boutelle, 2003). Two hundred seventy-seven adults were included in this telephone survey with a mean number of 2.6 children in each household. These data showed that interruptions during family mealtime such as television viewing during a meal is correlated with diets higher in fat and lower in fruits and vegetables. This indicates need for further study into the role that stress may play on the family mealtime environment. However, this study may also indicate to family nutrition educators that dinner time conversations should be kept pleasant. As researchers learn more about the family mealtime dynamic, they will become better able to adjust current interventions that will provide optimal education when dealing with families of overweight children/adolescents.

\section{Weight loss/ Maintenance Interventions}


Short-term efficacy in weight loss programs have used structured meal plans, but over the long-term structured meals could cause risky eating behaviors such as the denial of hunger cues or binge eating (Savoye et al., 2005). On the contrary, nonrestrictive approaches to meal planning may be a more realistic and more highly tolerated for longterm weight loss. There is also an association between non-restrictive methods of meal planning and the preservation of lean tissues in obese adolescents (Savoye et al., 2005). Savoye et al. (2005) compared structured meal plans versus a nonrestrictive, better choices approach and found that BMI in both groups of adolescents decreased after one year, but by two years post-intervention, only the nonrestrictive diet group had a consistent decrease in BMI compared to the structured meal plan group whose BMI seemed to return towards baseline. Information on weight management programs and interventions involving parents are lacking and should be further researched to gain knowledge for the prevention and treatment of child/adolescent obesity.

\section{Weight loss/ Maintenance Interventions Including Parents}

It is crucial, when working with children and adolescents to involve parents because of their impact on a child's life. A study was conducted that addressed the weight changes of 66 children and their mothers who participated in a family-based program. The study was designed to assist parents and children to modify their eating and activity behavior. The results showed that nutrition and activity education when combined with behavior modification was associated with a greater weight loss when compared to the group receiving nutrition and activity education only (Golan et al., 2004). Family-based interventions that involve realistic and coordinated goals for both parents and children in addition to positive reinforcements and behavior-changing tools appear to be effective in 
the treatment of child and adolescent overweight. Clearly, further research is necessary regarding the involvement of parents and behavior modifications in both children and parents to ensure the most advantageous treatment for child and adolescent obesity. 


\section{Chapter III:}

Methodology

Parent participation was based on their child's enrollment in Camp NEW You, a residential summer camp. Camp NEW You was designed by an interdisciplinary team of nutrition professionals, exercise scientists, psychologists, pediatricians, and educators from the state of West Virginia. Campers were recruited from a program developed to address risk factors for cardiovascular disease in West Virginia. The Coronary Artery Risk Detection in Appalachian Communities (CARDIAC) Project is a chronic disease risk surveillance and intervention initiative designed to battle the unacceptably high incidence of heart disease and diabetes in West Virginia. Camp NEW You was developed as an intervention program for CARDIAC participants. Campers' age ranged from 11 to 14 years. Requirements for attendance included a BMI at or above the $85^{\text {th }}$ percentile on CDC's US Growth Charts, a physician's referral, and the ability to participate in all camp activities. Parents and children were also asked to compose a letter of intent, promising their interest and participation for the duration of the one year program.

Camp NEW You consisted of a two-week residential camp full of fun physical activities, nutrition education, and healthy snacks. The camp was located on West Virginia University's campus. The aim of Camp NEW You was to encourage the participants to make better choices for weight management. Three follow-up weekends were also included and held at various locations in West Virginia. For the purposes of this study, only the initial summer intervention was examined. 
Prior to camp, families received a camp information package. This included what to bring, what to expect, and the "How Healthy Is Your Child's Environment?" checklist. Parents were asked to complete the survey prior to the start of camp.

Campers and parents arrived at camp and were introduced to camp staff. At this point, parents and campers were separated into their first breakout session. The parent education team, consisting of a health educator, a registered dietitian, and a dietetic graduate student presented the introductory education session. This session included increasing the knowledge of effective parent roles in children's health habits and its related research. Parents were introduced to the "How Healthy Is Your Child's Environment Checklist?” the Take Charge Program, activity log, parent resources, and purposes of each. The Take Charge program is a web-based program the adolescent campers used to track eating habits and physical activity progress. Six days later, parents returned for a weekend visit and additional break-out sessions. Saturday's session for parents focused on nutrition and physical activity. Parents were given ideas for making healthy food choices, portions and meal planning for weight management as well as skills to support healthy physical activities for weight management. Sunday’s break-out session involved a grocery store tour geared to increase knowledge of shopping, food label reading, and skills for eating out. Families gained knowledge of family mealtime and began goal setting strategies for their families. In total, the time spent educating parents was approximately nine hours throughout the initial intervention of Camp NEW You.

The environmental survey was developed by Camp NEW You parent education team based on existing surveys of a similar nature. The survey is included in the appendix 
and contains three components involving questions related to the home, school, and community environments. For the purpose of this study, only questions dealing with the home food environment have been analyzed. Questions regarding the home environment included those such as; "Are fruits and vegetables easy to see and ready for snacking?" “Does your child eat a healthy lunch every day?” This data were used for both parents and researchers to assess the adolescent's environment. It also enabled parents to discover specific and practical changes they can implement in their environment to support healthy habits for their families. For researchers, this tool helps determine the effectiveness of the parent education sessions on the home food environment.

\section{Study Subjects and Procedures}

The Institutional Review Board at West Virginia University previously approved research in this area using specified data. The study population consisted of 21 parents of overweight adolescents aged 10-14 years who were participating in Camp NEW You. Surveys were mailed to families prior to camp and parents were asked to bring their completed surveys with them to camp. In the weeks prior to the first follow-up weekend in October, the surveys were again mailed to each family. Parents returned their completed surveys at the beginning of the parent education session of the follow-up weekend. Data from these subjects came from the “How Healthy Is Your Child's Environment?” surveys at baseline in July 2008 and follow-up in October 2008. Each subject's name was assigned a code number and names were removed to ensure that subjects remained anonymous. Parents answered questions on a Likert scale with questions scored 1 through 5 . All survey questions were reviewed and data were entered into a database. 


\section{Data Analysis}

This study design is a pre- and post-intervention study that looked at family involvement and healthy food behaviors prior to nutrition education and three months after the nutrition education intervention. A factor analysis was performed to determine internal consistency and identify factors. An independent samples t-test was performed to test the hypothesis that parent education sessions offered as part of a residential summer camp was an effective tool in promoting a healthy home environment. All parent responses were averaged and compared to average responses at three month follow-up to examine changes occurring within the home food environment. Data collected were analyzed by the statistical software program, Statistical Package for the Social Sciences (SPSS for Windows, Version 16.0). Significance level was set at $\mathrm{p}<0.05$ 


\section{Chapter IV: \\ Results}

Questions to be analyzed were grouped together by a factor analysis so that questions were related to one another and measured the intended outcomes. The survey yielded two factors: family involvement and healthy lifestyle. Cronbach’s alpha was used to determine that internal consistency was adequate for both factors. (Table 2) The coefficients of the internal consistency based on Cronbach's alpha value for outcome expectations were 0.876 and 0.784 , respectively.

Results from the independent samples t-test revealed several differences between the initial data from July and the follow-up in October. Of the nineteen questions dealing with the home food environment, eleven questions showed significant differences. (Table $3 \&$ 4) Survey questions regarding parent’s perception of family mealtime revealed significant improvement in the amount of time spent together for meals each week. However, those question on whether dinner meals were served around the same time of day and if dinner conversations were pleasant showed no change. Questions dealing with variety of intake showed positive significant change from baseline to followup. The availability of healthy beverages like water and low-fat milk proved to be another area that showed significant change from baseline. The parents were also asked if meals were planned in advance. Results from this question showed positive change. Questions regarding whether fruits and vegetables are available for snacking and if the pantry and refrigerator are stocked with healthy snacks approached significance.

Parents’ perception regarding the eating of a healthy breakfast and lunch did not change from baseline. Neither did those questions asking if parents read nutrition labels. 
Questions asking if children helped with grocery shopping and meal preparation did not change from baseline.

\section{Table 2}

\section{Factor Analysis}

\begin{tabular}{lcc}
\hline $\begin{array}{l}\text { Variable } \\
\text { Factor Name: Healthy Lifestyle }\end{array}$ & $\begin{array}{c}\text { Eigenvalues } \\
\text { (Extraction ) }\end{array}$ & $\begin{array}{c}\text { Alpha } \\
\text { (overall) }\end{array}$ \\
\hline Are the pantry and refrigerator stocked with healthy snacks? & 0.684 & 0.876 \\
Are fruits and vegetables easy to see and ready for snacking? & 0.765 \\
\hline Does your child eat a variety of foods each day? & 0.719 \\
\hline Does your child eat a healthy breakfast every day? & 0.385 \\
\hline Are drinks such as water and low-fat milk available? & 0.697 \\
Does your child eat a healthy lunch every day? & 0.785 \\
\hline Do dinners include a variety of foods? & 0.765 \\
How often do you eat fresh foods such as raw vegetables and & 0.852 \\
fruits? & \\
When grocery shopping, do you read nutrition labels? & 0.571 \\
\hline Do you plan meals ahead of time? & 0.495 \\
\hline Does your child help shop for food? & 0.374 \\
\hline
\end{tabular}

\begin{tabular}{lcc}
\hline $\begin{array}{l}\text { Variable } \\
\text { Factor Name: Family Involvement }\end{array}$ & $\begin{array}{c}\text { Eigenvalues } \\
\text { (Extraction ) }\end{array}$ & $\begin{array}{c}\text { Alpha } \\
\text { (overall) }\end{array}$ \\
\hline $\begin{array}{l}\text { Does your family sit down together for dinner a few times a } \\
\text { week? }\end{array}$ & 0.887 & 0.784 \\
Are dinner meals served around the same time each day? & 0.830 \\
Are dinner mealtime conversations pleasant? & 0.366 \\
$\begin{array}{l}\text { Is the TV turned off during mealtime? } \\
\text { How often does your child eat at or carry out from fast-food } \\
\text { restaurants? }\end{array}$ & 0.630 \\
Does your child help fix meals? & 0.783 \\
\hline
\end{tabular}


Fisher

Table 3

Independent Samples T Test, Group Means, Pre \& Post Intervention

\begin{tabular}{|c|c|c|c|c|c|}
\hline \multicolumn{6}{|l|}{$\begin{array}{l}\text { Variable } \\
\text { Factor Name : Healthy Lifestyle }\end{array}$} \\
\hline Survey Questions & $\begin{array}{c}\text { Date } \\
\text { completed }\end{array}$ & Mean & $\begin{array}{l}\text { Standard } \\
\text { Deviation }\end{array}$ & $\mathbf{T}$ & $\begin{array}{c}\text { Significance } \\
\text { (2-tailed) }\end{array}$ \\
\hline \multirow{2}{*}{$\begin{array}{l}\text { Are the pantry and } \\
\text { refrigerator stocked with } \\
\text { healthy snacks? }\end{array}$} & July 2008 & 3.6500 & 0.87509 & $-1.889 \S$ & 0.067 \\
\hline & $\begin{array}{l}\text { October } \\
2008\end{array}$ & 4.1111 & 0.58298 & & \\
\hline \multirow{2}{*}{$\begin{array}{l}\text { Are fruits and vegetables easy } \\
\text { to see and ready for } \\
\text { snacking? }\end{array}$} & $\begin{array}{l}\text { July } 2008 \\
\text { October }\end{array}$ & 3.5500 & 0.99868 & $-1.190 \S$ & 0.064 \\
\hline & 2008 & 4.0556 & 0.53930 & & \\
\hline \multirow{2}{*}{$\begin{array}{l}\text { Does your child eat a variety } \\
\text { of foods each day? }\end{array}$} & July 2008 & 3.4000 & 0.82078 & $-2.063 *$ & 0.046 \\
\hline & $\begin{array}{l}\text { October } \\
2008\end{array}$ & 3.9444 & 0.80237 & & \\
\hline \multirow{2}{*}{$\begin{array}{l}\text { Does your child eat a healthy } \\
\text { breakfast every day? }\end{array}$} & July 2008 & 3.5000 & 0.88852 & -1.611 & 0.116 \\
\hline & $\begin{array}{l}\text { October } \\
2008\end{array}$ & 3.9444 & 0.80237 & & \\
\hline \multirow{2}{*}{$\begin{array}{l}\text { Are drinks such as water and } \\
\text { low-fat milk available? }\end{array}$} & July 2008 & 4.1500 & 1.13671 & $\begin{array}{c}- \\
2.906 * *\end{array}$ & 0.006 \\
\hline & $\begin{array}{l}\text { October } \\
2008\end{array}$ & 4.9444 & 0.23570 & & \\
\hline \multirow[t]{2}{*}{$\begin{array}{l}\text { Does your child eat a healthy } \\
\text { lunch every day? }\end{array}$} & July 2008 & 3.3000 & 0.73270 & $\begin{array}{c}- \\
2.793 * *\end{array}$ & 0.008 \\
\hline & $\begin{array}{l}\text { October } \\
2008\end{array}$ & 4.0000 & 0.79057 & & \\
\hline \multirow[t]{2}{*}{$\begin{array}{l}\text { Do dinners include a variety } \\
\text { of foods? }\end{array}$} & July 2008 & 3.6500 & 0.74516 & ${ }^{-}$ & 0.017 \\
\hline & $\begin{array}{l}\text { October } \\
2008\end{array}$ & 4.2222 & 0.64676 & & \\
\hline \multirow{2}{*}{$\begin{array}{l}\text { How often do you eat fresh } \\
\text { foods such as raw fruits and } \\
\text { vegetables? }\end{array}$} & July 2008 & 3.4000 & 0.68056 & $\begin{array}{c}- \\
3.563 * *\end{array}$ & 0.001 \\
\hline & $\begin{array}{l}\text { October } \\
2008\end{array}$ & 4.1765 & 0.63593 & 0.003 & \\
\hline \multirow[t]{2}{*}{$\begin{array}{l}\text { When grocery shopping, do } \\
\text { you read nutrition labels? }\end{array}$} & July 2008 & 3.0500 & 0.94451 & ${ }^{-}$ & 0.005 \\
\hline & $\begin{array}{l}\text { October } \\
2008\end{array}$ & 3.8889 & 0.75840 & & \\
\hline \multirow[t]{2}{*}{$\begin{array}{l}\text { Do you plan meals ahead of } \\
\text { time? }\end{array}$} & July 2008 & 2.8500 & 0.67082 & $\begin{array}{c}- \\
3.239 * *\end{array}$ & 0.003 \\
\hline & $\begin{array}{l}\text { October } \\
2008\end{array}$ & 3.6111 & 0.77754 & & \\
\hline \multirow{2}{*}{$\begin{array}{l}\text { Does your child help shop for } \\
\text { food? }\end{array}$} & July 2008 & 3.0000 & 0.85840 & -1.353 & 0.185 \\
\hline & $\begin{array}{c}\text { October } \\
2008\end{array}$ & 3.3529 & 0.70189 & & \\
\hline
\end{tabular}


Table 4

Independent Samples T Test, Group Means, Pre and Post Intervention

\begin{tabular}{|c|c|c|c|c|c|}
\hline \multicolumn{6}{|c|}{$\begin{array}{l}\text { Variable } \\
\text { Factor Name: Family Involvement }\end{array}$} \\
\hline Does your family sit down & July 2008 & 3.6000 & 1.09545 & $-2.393^{*}$ & 0.022 \\
\hline times a week? & $\begin{array}{l}\text { October } \\
2008\end{array}$ & 4.3889 & 0.91644 & & \\
\hline \multirow{2}{*}{$\begin{array}{l}\text { Are dinner meals served } \\
\text { around the same time each } \\
\text { day? }\end{array}$} & July 2008 & 3.6500 & 0.93330 & -1.254 & 0.218 \\
\hline & $\begin{array}{l}\text { October } \\
2008\end{array}$ & 4.0000 & 0.76696 & & \\
\hline \multirow{2}{*}{$\begin{array}{l}\text { Are dinner mealtime } \\
\text { conversations pleasant? }\end{array}$} & July 2008 & 4.0000 & 0.56195 & 0.00 & 1.00 \\
\hline & $\begin{array}{l}\text { October } \\
2008\end{array}$ & 4.0000 & 0.79057 & & \\
\hline \multirow{2}{*}{$\begin{array}{l}\text { Is the TV turned off during } \\
\text { mealtime? }\end{array}$} & July 2008 & 2.6500 & 1.03999 & - & 0.001 \\
\hline & $\begin{array}{l}\text { October } \\
2008\end{array}$ & 3.8824 & 1.11144 & & \\
\hline \multirow{2}{*}{$\begin{array}{l}\text { How often does your child eat } \\
\text { at or carry out from fast-food } \\
\text { restaurants? }\end{array}$} & July 2008 & 2.5556 & 0.61570 & - & 0.011 \\
\hline & $\begin{array}{l}\text { October } \\
2008\end{array}$ & 3.1000 & 0.64072 & & \\
\hline \multirow{2}{*}{$\begin{array}{l}\text { Does your child help fix } \\
\text { meals? }\end{array}$} & July 2008 & 3.0500 & 0.82558 & -1.427 & 0.162 \\
\hline & $\begin{array}{l}\text { October } \\
2008\end{array}$ & 3.3889 & 0.60768 & & \\
\hline
\end{tabular}




\section{Chapter V: \\ Discussion}

Based on the survey results of this study, it appears the initial education sessions for Camp NEW You parents was effective in positively changing the home food environment. The parent perceptions before and after the nine hour initial summer intervention showed significant differences in eleven of nineteen areas that dealt with the home food environment. Several factors have been associated with healthy dietary behaviors. Among the strongest are food availability and accessibility of healthy foods, the frequency of family meals, and parental intake and parenting practices (Story et al, 2008). These are areas that were addressed within parent education sessions and also areas in which significant changes occurred.

As mentioned previously, the factor analysis yielded two factors. The healthy lifestyle factor encompasses questions from the survey dealing with the types of food within in the home and the types of foods that are purchased for the home. Significant changes occurred in questions dealing with healthy food choices including increased availability of low-fat milk, water, and fresh foods like raw fruits and vegetables. $(p<0.02)$ There was also a significant change in responses pre- and post-intervention that indicated an increase in the variety of foods being consumed. Lesson objectives in the parent education sessions that dealt with increasing knowledge about healthy food choices, portion control and meal planning may be a contributing factor to this change. These results are consistent with those showing that when parental knowledge about nutrition increases, that better food choices are made (Räsänen et al., 2003). There was also a significant difference in the question regarding nutrition label reading while 
grocery shopping. $(\mathrm{p}<0.02)$ The grocery store tour that parents attended on the last day of camp may have played an influential role in the changes seen from survey data. The grocery store tour was a more hands on experience, which allowed parents to ask questions regarding healthy food choices. There were two questions among survey questions that were not statistically significant but were approaching significance. These questions dealt with the availability of healthy snacks within the home. Although, not statistically significant, the mean responses pre- and post-intervention scored relatively high to begin with indicating little room for improvement.

The second factor identified, family involvement, dealt with questions regarding family meals and the environment in which they occur. Questions within this factor also dealt with fast food consumption. Based on parent perceptions, the occurrence of family meals significantly improved. $(\mathrm{p}<0.05)$ Significant changes also occurred with the question asking if the television was turned off during mealtime. $(\mathrm{p}<0.02)$ Both family meal frequency and television viewing during meal times were addressed within the education sessions and this may have contributed to the positive change that was seen. In 2007, Feldman and colleagues found that watching television during meal times was associated with poor diet quality among adolescents. Another factor showing significant change dealt with the amount of time the family ate food from a restaurant. $(\mathrm{p}<0.02)$ This component was also addressed during camp education sessions which may be attributed to the positive change shown by the data. Three questions within this factor did not show significant improvement including questions dealing with mealtime preparation and conversations and whether meals are served at the same time every day. These questions 
did not show significance most likely because mean responses were very similar at both pre and post-intervention.

The application of the environmental checklist helped identify variables of the Home Environment that changed significantly and those that did not. This could lead to changes in the parent education sessions in the future. The campers' perception of the home environment is one area that should be examined to compare camper's perceptions of environment to that of the parents. While both campers and parents were provided education materials and invited to share feedback, future renditions of this program should focus on combining some of the educational activities for both groups. By educating both parents and children together, the family would learn the same skills to identify, adopt, and utilize healthy behaviors. Parents play a role in the home environment but do not make up its entirety, therefore, the family unit should be considered. Encouraging the family as a whole to be positive agents of change for each other will help participants during the maintenance phase of these lifestyle changing behaviors.

The goals outlined by the Healthy People 2010 Guidelines include the promotion of proper nutrition (USDHHS, 2000). Because this is an ongoing study, estimates of the changes in the nutrition environment should be documented throughout the remainder of Camp NEW You. The parent education sessions provided education regarding healthy food choices, portion control, and meal planning for weight management, all of which could lead toward meeting goals set by Healthy People 2010. The results from the environmental checklist appear to show an increase in nutrition knowledge based on parent perceptions of their own home environments as a whole. Increases in parent 
knowledge of nutrition and its relationship to weight status of adolescents have been studied previously. Increased parental nutrition knowledge has been linked to decreases in the incidence of overweight adolescents. Also, it should be noted that when parents have a greater knowledge of nutrition that diet quality of their adolescents improves (Nelson et al, 2009). Most of the changes that occurred were considered statistically significant, and those approaching significance were those dealing with healthy snacks including fruits and vegetables. Studies have shown that diet quality during adolescence is predictive of meal patterns and quality in that of young adults (Larson, 2007).

\section{Study Strengths and Limitations}

This study may be unique in that the effectiveness between parent education sessions and changes in the home food environment were examined. Many current studies look specifically at family meals and BMI, or diet quality. Other studies combine child and adolescent overweight. By including parents, the whole family unit may be examined and could provide details into how the home environment influences eating behaviors.

There are some limitations to this study. The main limitation of the study is that there was no control group. Data from this study should be compared to a control group receiving no education and also with data from a follow-up study to monitor the quality of the education provided to parents and the changes taking place within the home food environment. A control group that was not given parent education sessions would be beneficial in comparing the effectiveness of the education sessions. Another major limitation to the study was the small sample size of 21 subjects. A larger sample size 
would better approximate the population so that the statistics could be generalized to the rest of the population. In order to improve the quality of the study, adjustments should be made to the survey in order to receive more specific data regarding the home food environment. For example, the survey question involving family meals could be reformatted to better determine the number of times families sit down to dinner each week. Parent perceptions also serve as a limitation to the study in that parents may embellish survey responses or may have entirely different response than those of their children.

Data from this study will benefit researchers in that it will give feedback on what changes can be made to the parent component of Camp NEW You in the future. This will ensure successful program implementation that may help to treat adolescent overweight. 


\section{Application}

While there was no control group for this study that would attribute change to the education sessions provided as part of Camp NEW You, this study has the potential to emerge as a longitudinal study of this at-risk population. The environmental survey and Healthy People 2010 guidelines provided a useful framework for evaluation of the effectiveness of Camp NEW You parent education for future renditions. Obesity prevention requires the formation and sustainability of partnerships including the family as a whole. The short-term goals of the initial summer intervention have been accomplished in that significant changes were reported in the home food environment of parent participants based on their own perceptions. The long-term goals of Camp NEW You are to establish lifestyle changes that will assist in reducing unhealthy body weight through increased physical activity and good nutrition. The Camp NEW You intervention provides the framework for the longitudinal study of this group of adolescents that began the program at a younger age. With continued support from the CARDIAC Project and WVU dietetics, the program can be perpetuated indefinitely. Children enrolled in Camp NEW You ranged in age from 11-14 years and most of the children expressed the desire to return again the following year. This would provide a unique environment for continuous follow-up of the population. Future research could include more extensive examination of the diet quality as perceived by both parents and adolescents participating in camp. Baseline and follow-up anthropometric data could also be obtained from parents and campers which would allow for even more research within the population. Long-term prospective studies and further engagement of parents and campers is necessary to fully 
Fisher

understand the effect of the home food environment on the healthy lifestyles of this population. 


\section{References}

American Obesity Association. Childhood Overweight (2008). American Obesity Association. Retrieved April 25, 2008, from http://www.obesity.org/information/childhood_overweight.asp

Barlow SE, Dietz WH. Obesity evaluation and treatment: expert committee recommendations. Pediatrics. 1998;102:e29

Boutelle KN, Birnbaum AS, Lytle LA, Murray DM, Story M. Associations between pervceived family meal environment and parent intake of fruit, vegetables, and fat. J Nutr Educ Behav. 2003; 35:24-29

Centers for Disease Control and Prevention (CDC). National Center for Health Statistics (NCHS). National Health and Nutrition Examination Survey Data. Hyattsville, MD: U.S. Department of Health and Human Services, Centers for Disease Control and Prevention, 2004. http://www.cdc.gov/nchs/data/hus/hus04trend.pdf\#070

Centers for Disease Control and Prevention and Health Promotion. Overweight and Obesity: Overweight Prevalence. Accessed April 22, 2008 http://www.cdc.gov/nccdphp/dnpa/obesity/childhood/prevalence.htm

Crossman A, Sullivan DA, Benin M. The family environment and American adolescents' risk of obesity as young adults. Soc Sci \& Med. 2006; 63:2255-2267

Daniels S R, Arnett D K, Eckel R H, et al. Overweight in children and adolescents: pathophysiology, consequences, prevention and treatment. Journal of the American Heart Association. 2005; 111:1999-2012.

Daniels SR, Kimball TR, Morrison JA, Khoury P, Witt S, Meyer RA. Effect of lean body mass, fat mass, blood pressure, and sexual maturation on left ventricular mass in children and adolescents. Circulation. 1995; 92:3249-3254

Eisenberg ME, Olson RE, Neumark-Sztainer D, Story M, Bearinger LH. Correlations between family meals and psychosocial well-being among adolescents. Archives of Pediatrics \& Adolescent Medicine. 2004; 158: 792-796

Eisenberg ME, Neumark-Stzainer D, Story M. Associations of weight-based teasing and emotional well-being among adolescents. Arch Pediatr Adolesc Med. 2003; $157: 733-738$

Evans J \& le Grange D. Body size and parenting in eating disorders: A comparative study of the attitudes of mothers toward their children. International Journal of Eating Disorders. 1995; 18:39-48

Farooqi IS, Jebb SA, Langmack G, Lawrence E, Cheetham CH, Prentice AM, Hughes IA, McCamish MA, O'Rahilly S. Effects of recombinant leptin therapy in a child with congenital leptin deficiency. $N$ Engl J Med. 1999; 341:879-884 
Feldman S, Eisenberg ME, Neumark-Stainer D, Story M. Associations between watching TV during family meals and dietary intake among adolescents. J Nutr Ed Behav. 2007. 39 (5):257-263

Fletcher GF, Balady G, Blair SN, Blumenthal J,Caspersen C, Chaitman B, Epstein S, Sivarajan Froelicher ES, Froelicher VF,Pina IL, Pollock ML,.Statement on Exercise: Benefits and Recommendations for Physical Activity Programs for All Americans. (1996) Accessed on February 10, 2008 from http://circ.ahajournals.org/cgi/content/full/94/4/857

Golan M, Crow S. Parents are key players in the prevention and treatment of weightrelated problems. Nutr Rev. 2004; 62:39-50

Goodman E, Whitaker RC. A Prospective study of the role of depression in the development and persistence of adolescent obesity. Pediatrics. 2002;110:497-504

Groesz LM, Levine MP, Murnen SK. The effect of experimental presentation of thin media images on body satisfaction: a meta-analytic review. Int J Eat Disord. 2002; 31:1-16.

Heady JA, Morris JN, Raffle PA. Physique of London busmen: epidemiology of uniforms. Lancet. 1956; 84:633-641

Hoelscher DM, Feldman HA, Johnson CC, Lytle LA, Osganian SK, Parcel GS, Kelder $\mathrm{SH}$, Stone EJ, Nader PR. School-based health education programs can be maintained over time: results from CATCH Institutionalization Study. Preventive Medicine. 2004; 38:594-606

Kelder SH, Perry CL, Lytle LA, Klepp K. Communtiy-wide youth nutrition education: long-term outcomes of the Minnesota Heart Health Program. Health Education Research. 1995; 10(2):119-131

Langevin DD, Kwiatkowski C, McKay MG, Maillet JO, Touger-Decker R, Smith JK,Perlman A. Evaluation of diet quality and weight status of children from low socioeconomic urban environment supports “At Risk” classification. J Am Diet Assoc. 2007; 107: 1973-1977

Larson NI, Nuemark-Sztainer D, Harnack LJ, Wall MM, Story M, Eisenberg ME. Fruit and vegetable intake correlates during the transition to young adulthood. American Journal of Preventive Medicine. 2008; 35:33-37

Larson NI, Neumark-Sztainer D, Hannan PJ, Story M. Family meals during adolescence are associated with higher diet quality and healthful meal patterns during young adulthood. J Am Diet Assoc. 2007;107: 1502-1510

McMinn JE, Baskin DG, Schwartz MW. Neuroendocrine mechanisms regulating food intake and body weight. Obes Rev. 2000; 1:37-46. 
Messina CR, Weidner G, Connor SL. Mother's attitudes toward nutrition are related to daughters’ but not sons’ plasma cholesterol levels. J Am Diet Assoc. 202; 102: 678-682

Nelson MC, Lytle LA, Pasch KE. Improving Literacy about Energy-Related Issues: The Need for a Better Understanding of the Concepts behind Energy Intake and Expenditure among Adolescents and Their Parents. J Am Diet Assoc 2009; 109 : 281-287

Neumark-Sztainer D. Eating Among Teens: Do family mealtimes make a difference for adolescents' nutrition? New Directions for Child and Adolescent Development. 2006; 111:91-105

The National Heart Lung and Blood Institute. 2008. Metabolic Syndrome: What is metabolic syndrome? Accessed April 28, 2008 http://www.nhlbi.nih.gov/health/dci/Diseases/ms/ms_whatis.html

Panel on Macronutrients, Subcommittees on Upper Reference Levels of Nutrients and Interpretation and Uses of Dietary Reference Intakes, and the Standing Committee on the Scientific Evaluation of Dietary Intakes. 2002. Dietary Reference Intakes for Energy, Carbohydrate, Fiber, Fat, Fatty acids, Cholesterol, Protein, and Amino Acids (Macronutrients). Washington, DC: National Academies Press.

Position of the American Dietetic Association: Individual-, Family-, School-, and Community-Based Interventions for Pediatric Overweight. 2006; 106:925-945

Räsänen M, Niinikoski H, Keskinen S, Helenius H, Talvia S, Rönnemaa T, Viikari J, Simell O. Parental nutrition knowledge and nutrient intake in an atherosclerosis prevention project: the impact of child-targeted nutrition counseling. Appetite. 2003. 41:69-77

Rhee K. Childhood overweight and the relationship between parent behaviors, parenting style, and family functioning. Ann Am Acad Pol Soc Sci 2008; 615:1137

Rosenkranz RR and Dzewaltowski DA. Model of the home food environment pertaining to childhood obesity. Nutr Rev. 2008; 66:123-140

Sallis JF, Prochaska JJ, Taylor WC. A review of correlates of physical activity of children and adolescents. Sci Sports Exerc. 2000; 32:963-975

Savoye M, Berry D, Dziura J, . Shaw M, Serrecchia JB, Barbetta G, Rose P, Lavietes S, Caprio S.Anthropometric and psychosocial changes in obese adolescents enrolled in a weight management program. J Am Diet Assoc. 2005; 105:364-370

Sen, B. Frequency of family dinner and adolescent body weight status: Evidence from the National Longitudinal Survey of Youth, 1997. Obesity (Silver Spring) 2006;

$14: 2266-2276$ 
Society for Adolescent Medicine. Position of the Society for Adolescent Medicine:

Preventing and treating adolescent obesity. 2006; 38:784-787

Story M, Kaphingst KM, Robinson-O’Brien R, Glanz K. Creating Healthy Food and Eating Environments: Policy and Environmental Approaches. Annu Rev Public Health 2008; 29:253-72

Story M, Neumark-Sztainer D, French S. Individual and environmental influences on adolescent eating behaviors. Supplement to the J Am Diet Assoc. 2002; 102: S40S51

Taveras EM, Rifas-Shiman S, Berkey CS, Rockett HRH, Field AE, Frazier AL, Colditz GA, Gillman MW. Family Dinner and Adolescent Overweight. Obes Res. 2005; 13(5): $900-906$

U.S. Census Bureau, 2005 American Community Survey. Accessed March 5, 2009. http://www.census.gov/population/www/popprofile/files/dynamic/MoneyIncome.pdf

United States Dept. of Agriculture: Economic Research Service: Data Sets. State Fact Sheets: West Virginia. 2008. Accessed April 24, 2008. http://www.ers.usda.gov/statefacts/WV.htm\#PIE

United States Dept. of Health and Human Services, Centers for Disease Control and Prevention. Physical Activity and Health: A Report of the Surgeon General. Atlanta, GA: National Center for Chronic Disease Prevention and Health Promotion; 1996

Variyam JN. Overweight Children: Is parental knowledge a factor? Food Review. 2001; 24:18-22

Visser, RWM. Early efforts make a world of difference in preventing childhood obesity. Total Health. 2005; 27: 48-50

West Virginia Department of Health and Human Resources. Obesity: Facts, Figures, Guidelines. 2002. Accessed on April 21, 2008. http://www.wvdhhr.org/bph/oehp/obesity/default.htm

Whitaker RC, Wright JA, Pepe MS, Seidel MS, Dietz WH. Predicting obesity in young adulthood from childhood and parental obesity. N Engl J Med 1997; 337:869-873

Williams CL, Hayman LL, Daniels SR, Robinson TN; Steinberger J; Paridon S; Bazzarre T. Cardiovascular Health in Childhood: A statement for health professionals from the Committee of Atherosclerosis, Hypertension, and Obesity in the Young (AHOY) of the Council Cardiovascular Disease in the young. Circulation. 2002; 106:143-160 
Fisher

\section{APPENDICES}

Appendix A: How Healthy Is Your Child’s Environment? Survey...............43

Appendix B: Parent Education Sessions Objectives...........................49 


\section{WestVirginiaUniversity}

\section{How Healthy Is Your Child's Environment?}

Answer these questions to find clues to your child's eating and fitness environment. Use it to discover practical changes to support healthy habits at home, at school, and in your community.

If you do not know the answer to a question, leave it blank.

HOME

1. Are the pantry and refrigerator stocked with healthy snacks, such as fresh fruit, low-fat dairy products and whole-grain cereals and bars? Never Rarely Sometimes Often Always

2. Are fruits and vegetables easy to see and ready for snacking?
Never
Rarely
Sometimes
Often
Always

3. Does your child eat a variety of foods each day - fruits, vegetables, protein, dairy, grains?
Never
Rarely
Sometimes
Often
Always

4. Does your child eat a healthy breakfast every day?

Never Rarely Sometimes Often Always

5. Are drinks such as water and low-fat milk available instead of soda and fruit drinks?

Never Rarely Sometimes Often Always

6. Does your child eat a healthy lunch every day?

Never Rarely Sometimes Often Always

7. Does your family sit down together for dinner a few times a week?

Never Rarely Sometimes Often Always
8. Are dinner meals served around

the same time each day?

$\begin{array}{lll}\text { Never } & \text { Rarely } & \text { Sometimes } \\ \text { Often } & \text { Always } & \end{array}$

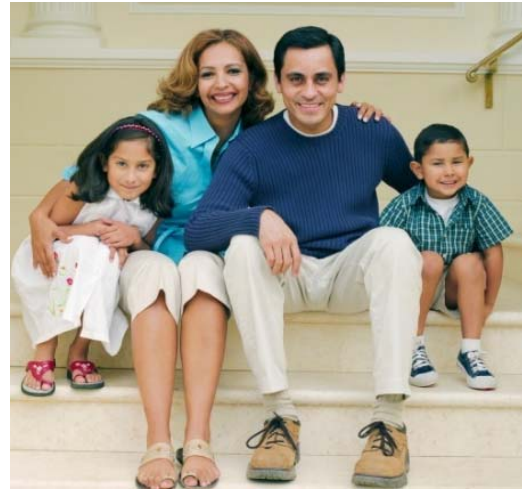

9. Are dinner mealtime conversations pleasant?

Never Rarely Sometimes Often Always

10. Is the TV turned off during mealtime?

Never Rarely Sometimes Often Always

11. Do you encourage your child to stop eating when they are not hungry? Never Rarely Sometimes Often Always

12. Do dinners include a variety of foods - fruits, vegetables, protein, dairy, grains?

Never Rarely Sometimes Often Always

13. How often do you eat fresh foods such as raw vegetables and fruits?

Never Rarely Sometimes Often Always

14. How often does your child eat at or carry out from fast-food restaurants?

Never Rarely Sometimes Often Always

15. Do you give food to your child to reward good behavior? Never Rarely Sometimes Often Always 
16. When grocery shopping, do you read nutrition labels?

Never Rarely Sometimes Often Always

17. Do you plan meals ahead of time?

Never Rarely Sometimes Often Always

18. Does your child help shop for food?

Never Rarely Sometimes Often Always

19. Does your child help fix meals?

Never Rarely Sometimes Often Always

20. Do you set limits on how many hours your child can watch TV, play video games, or talk on the phone?

Never Rarely Sometimes Often Always

21. Does your family do physical activities together?

Never Rarely Sometimes Often Always

22. Does your child have access to sports or exercise equipment in your home such as balls, bikes, and jump ropes?
Never
Rarely
Sometimes
Often
Always

23. Are you physically active for at least $\mathbf{3 0}$ minutes or more on all or most days of the week?

Never Rarely Sometimes Often Always

24. Is your child physically active for a total of 60 minutes or more on all or most days of the week?
Never
Rarely Sometimes
Often
Always

25. Does your child walk to school?
Never
Rarely
Sometimes
Often
Always

26. Does your child participate in "everyday physical activities," such as indoor/outdoor chores, gardening, yard work, playing with pets, etc.?
Never
Rarely
Sometimes
Often
Always

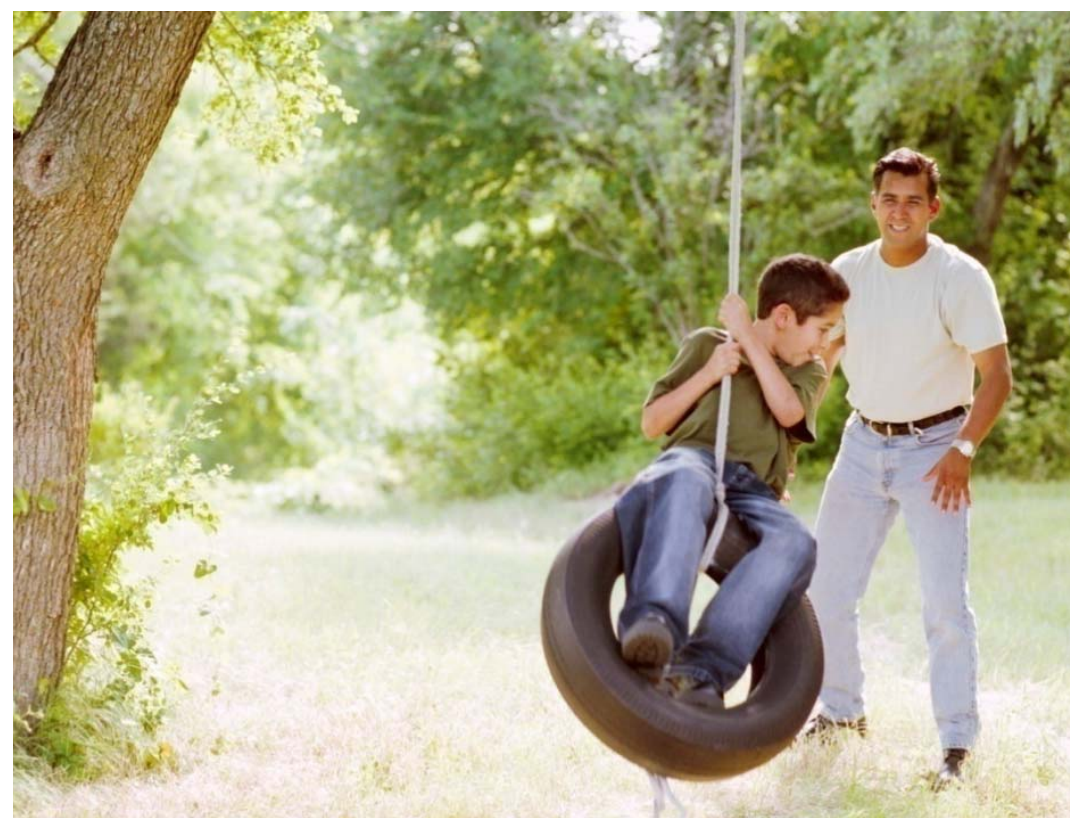

27. Does your child participate on a sports team, such as soccer, basketball, or softball?

Never Rarely Sometimes Often Always

28. Does your child participate in physical activities alone or with friends, such as biking, walking, tennis, swimming?

Never Rarely Sometimes Often Always

29. Does your child play physically active videogames at home, such as DDR or Wii ?

Never Rarely Sometimes Often Always

30. Do you pick family activities that are physically active?
Never
Rarely
Sometimes
Often
Always

31. Do you set exercise and physical activity goals for yourself?

Never Rarely Sometimes Often Always

32. Do you help your child set physical activity goals?
Never
Rarely
Sometimes
Often
Always 
1. Does your child's school have a comfortable place to sit to eat breakfast and lunch?

Never Rarely Sometimes Often Always

2. Do you - or your child - pack a healthy bag lunch for school? Never Rarely Sometimes Often Always

3. Does the cafeteria have healthy choices, like salad bars or vegetarian entrees?

Never Rarely Sometimes Often Always

4. Can students buy foods high in sugar, fat, and sodium at a school store or cafeteria or from vending machines?
Never
Rarely
Sometimes
Often
Always

5. Are candy, soda, and other unhealthy foods sold as school fundraisers?
Never
Rarely
Sometimes
Often
Always

6. Does your child's school get money from food or beverage companies in exchange for product sales, signs, or advertising?
Never
Rarely
Sometimes
Often Always

7. Does the school have contracts with fast-food companies to offer these foods at lunch?

Never Rarely Sometimes Often Always

8. Do the school water fountains work?

Never Rarely Sometimes Often Always

9. Does your child participate in physical education class at least 3 times a week (for elementary) or 5 days a week for 9 weeks (middle school)?
Never
Rarely
Sometimes
Often
Always

10. Does your child participate in any after-school or outside-of-school sports or physical activities? Never Rarely Sometimes Often Always

11. Are there planned physical activities for your child to do before school and/or at lunchtime? Never Rarely Sometimes Often Always

12. Is your child sure about his/her ability to participate in physical education or other physical activities at school with their peers?

Never Rarely Sometimes Often Always

13. Do the activities in your child's school physical education program match their needs/abilities/interests?

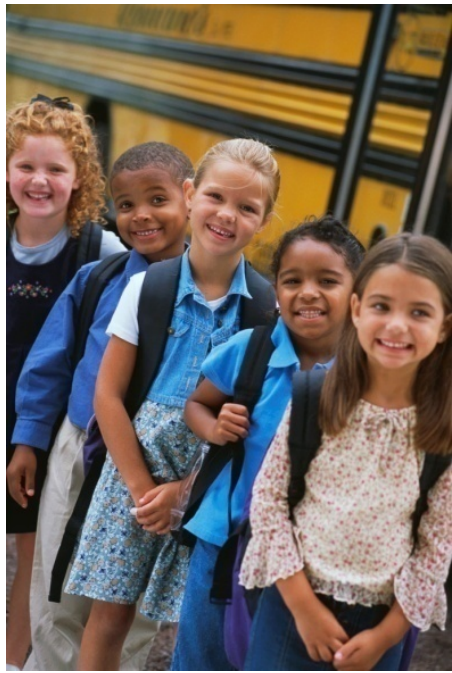

14. Is your child teased about his/her weight or shape? Never Rarely Sometimes Often Always

15. Are speakers brought to class to talk about healthy eating and fitness with parents, teachers, and students?

Never Rarely Sometimes Often Always

16. Are students taught about the importance of healthy eating and regular physical activity?

Never Rarely Sometimes Often Always

17. Are there school guidelines for referring students to health care providers, if needed?

Never Rarely Sometimes Often Always

18. Are school teachers and administrators good role models for healthy eating and physical activity?

Never Rarely Sometimes Often Always 


\section{COMMUNITY}

1. Is it safe for your child to play outdoors without adult supervision?
Never
Rarely
Sometimes
Often
Always

2. Are there bike paths, hiking trails, swimming pools, or parks in your neighborhood? Never

Rarely

Sometimes

Often Always

3. Are there community sports teams or clubs that your child can join that are low cost? Neve

Rarely

Sometimes

Often

Always

4. Is there a church or community center nearby that has fun, physical activities such as basketball, dance or self-defense?

Never Rarely Sometimes

Often Always

5. Is it easy for parents to find community resources on nutrition and fitness?

Never Rarely Sometimes Often Always

6. Are there places within walking distance to buy healthy snacks?
Never
Rarely
Sometimes
Often
Always

7. Overall, how would you rate each part of your child's environment? Check one rating for each environment:

\begin{tabular}{|l|l|l|l|l|}
\hline & $\begin{array}{c}\text { Not } \\
\text { Healthy }\end{array}$ & A Little Healthy & Mostly Healthy & $\begin{array}{c}\text { Very } \\
\text { Healthy }\end{array}$ \\
\hline Home & & & & \\
\hline School & & & & \\
\hline After School & & & & \\
\hline Community & & & & \\
\hline
\end{tabular}

8. What are your 3 biggest concerns about your child's environment? Please list:
b)
c)

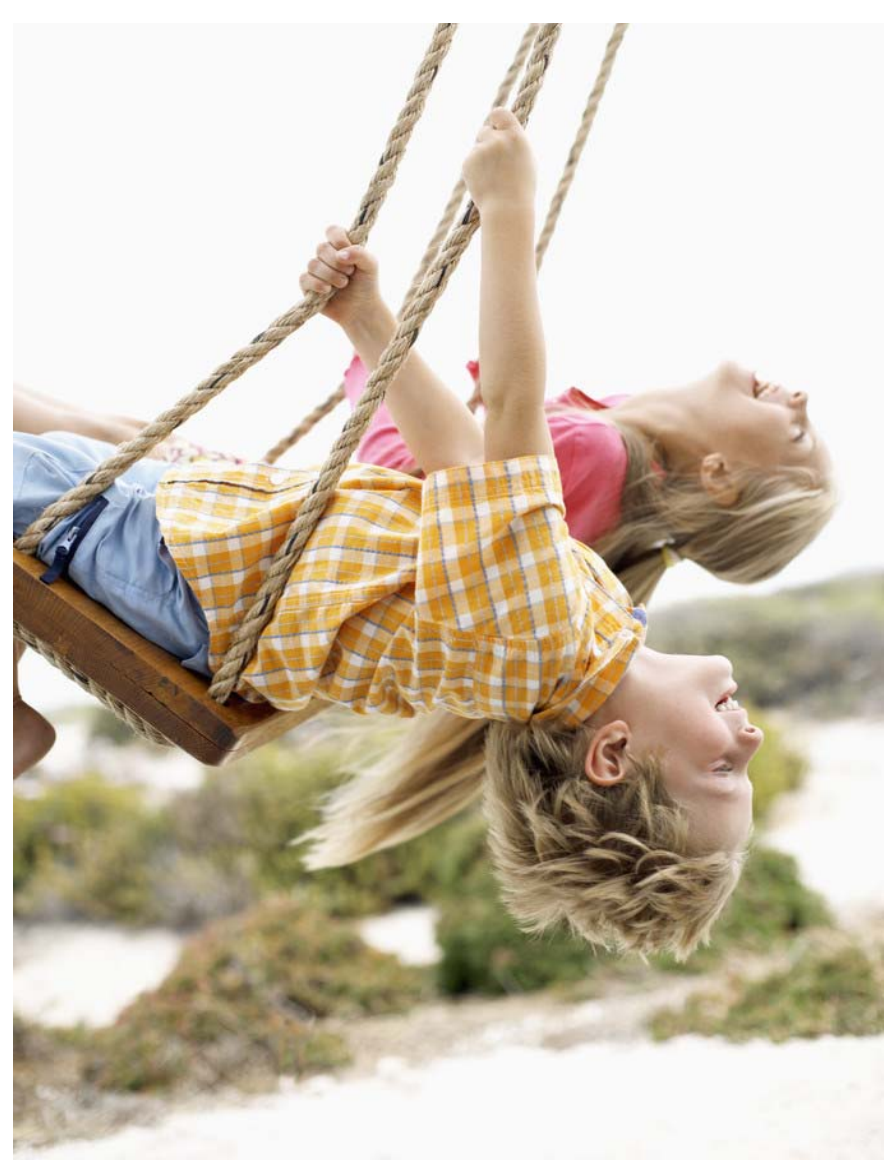

Thank You! 


\title{
APPENDIX B: Camp NEW You Parent Education Session Objectives
}

\author{
Camp NEW You for Parents \\ Parent Session \\ Sunday, July 13, 2008 2:45-4:15 pm
}

\section{Learning Objectives:}

1. to increase knowledge of effective parent roles in children's health habits and related research

2. to introduce parents to an environmental assessment tool

3. to introduce Take Charge program, activity log, and parent resources

\section{Materials:}

- BodyWorks family toolkits

- How Healthy is Your Child's Environment?

- We Can! Parent Handbook

- Nutrition Crash Course Parent Workbook

- Cindy Says book

- Complications of Overweight handout

- PowerPoint

- Music

- Flipchart \& markers

- Parent Postcards to Campers

Outline:

\begin{tabular}{|c|c|c|}
\hline Time & Lead Presenter & Topic/Activity \\
\hline $\begin{array}{l}\text { 2:45- } \\
3: 00\end{array}$ & Elaine & $\begin{array}{l}\text { - Introductions } \\
\text { - Icebreaker Activity (form } 2 \text { circles; circles walk in opposite } \\
\text { directions to the music; when music stops, pair up and answer } \\
\text { question) } \\
\text { - Overview of Parent Sessions \& Philosophy (PowerPoint) }\end{array}$ \\
\hline $\begin{array}{l}3: 00- \\
3: 25\end{array}$ & Kim & $\begin{array}{l}\text { - Overview of Habits of Highly Effective, HEALTHY families; } \\
\text { parent role research (PowerPoint) } \\
\text { - Role play activity and discussion }\end{array}$ \\
\hline $\begin{array}{l}3: 25- \\
3: 30\end{array}$ & Kim & How Healthy is Your Child’s Environment? (handout) \\
\hline $\begin{array}{l}3: 30- \\
3: 40\end{array}$ & Elaine & $\begin{array}{l}\text { Introduction of Parent Tools - } \\
\text { 1. BodyWorks kit } \\
\text { 2. We Can! Parent Handbook } \\
\text { 3. Nutrition Crash Course Workbook }\end{array}$ \\
\hline
\end{tabular}




\begin{tabular}{|c|c|c|}
\hline & & 4. Cindy Says, "You Can Find Health in Your Hectic World" \\
\hline $\begin{array}{l}3: 40- \\
3: 45\end{array}$ & Eloise & $\begin{array}{l}\text { Take Charge -overview of what kids’ TC e-learning + parent } \\
\text { resources }\end{array}$ \\
\hline $\begin{array}{l}3: 45- \\
3: 55\end{array}$ & Elaine & $\begin{array}{l}\text { (STRETCH BREAK!) } \\
\text { Key Learning Concepts for CNY Parent Sessions (PowerPoint) } \\
\text { Getting Started This Week - Parent's To Do List: } \\
\text { - } \quad \text { Review BodyWorks kit } \\
\text { - } \quad \text { Complete How Healthy is Your Child's Environment } \\
\text { - } \quad \text { Read pages BodyWorks pages 1-31 } \\
\text { - } \quad \text { Start your Journal (optional) }\end{array}$ \\
\hline $\begin{array}{l}3: 55- \\
4: 10\end{array}$ & Dr. Bill Neal & Doc Talk - Complications of Overweight handout/Q\&A \\
\hline 4:15 & Elaine/Kim & $\begin{array}{l}\text { Wrap Up } \\
\text { - Parents write a postcard to their child - for ideas, they can start } \\
\text { with one of these questions: } \\
\text { - “I'm excited about Camp NEW You because I will...” } \\
\text { - “I'm on your team because I want to ...” } \\
\text { - " } \text { - Quest's important for us to work together so we can...” }\end{array}$ \\
\hline
\end{tabular}




\section{Camp NEW You for Parents \\ Parent Session "Tips and Tricks of Eating Smart" \\ Saturday, July 19, 2008 3:00-5:30 pm Towers/Blue Room}

\section{Learning Objectives:}

4. to increase knowledge and skills in supporting healthy food choices, portions, and meal planning for weight management

5. to increase knowledge and skills in supporting healthy physical activities for weight management

Materials:

- Laptop/LCD projector

- BodyWorks family toolkits

- Nutrition Crash Course Parent Workbook

- PowerPoint

- Flipchart \& markers

- Calculators

- Snack foods

- Food labels

- Portion size materials (foods, equip)

- Parent Resource Table

Outline:

\begin{tabular}{|c|c|c|}
\hline Time & Lead Presenter & Topic/Activity \\
\hline $\begin{array}{l}3: 00- \\
3: 10\end{array}$ & Elaine & $\begin{array}{l}\text { - Parents turn in completed How Healthy is Your Child's } \\
\text { - Environment } \\
\text { - Get a snack } \\
\text { - Write on a flipchart "What I want to know about nutrition..." }\end{array}$ \\
\hline $\begin{array}{l}3: 10- \\
3: 40\end{array}$ & Eric & Kids’ Update \\
\hline $\begin{array}{l}\text { 3:40- } \\
5: 40\end{array}$ & Kristen & $\begin{array}{l}\text { Energy IN } \\
\text { Nutrition Crash Course (PowerPoint) } \\
\quad \text { Basics of MyPyramid choices, portions, meal planning, quiz }\end{array}$ \\
\hline 5:40 & & Wrap up/Q\&A \\
\hline
\end{tabular}




\section{Camp NEW You for Parents}

Sunday, July 20, 2008

Parent Sessions “Grocery Shopping Challenge” 9:00 -11:30 am at Krogers

and "Putting Your Knowledge to Work at Home” 1:00-2:30 pm Towers JB Lounge

Learning Objectives:

1. to increase shopping, food label reading, (GROCERY STORE TOUR) and eating out skills

2. to gain decision-making skills in improving the home environment

3. to increase knowledge of family mealtime and plan strategies

Materials:

- BodyWorks family toolkits

- How Healthy is Your Child's Environment?

- We Can! Parent Handbook

- PowerPoint

- $\quad$ Flipchart \& markers

Outline:

\begin{tabular}{|c|c|c|}
\hline Time & Lead Presenter & Topic/Activity \\
\hline $\begin{array}{l}1: 00- \\
1: 30\end{array}$ & Elaine & $\begin{array}{l}\text { Move More } \\
\text { Barriers } \\
\text { Screentime }\end{array}$ \\
\hline $\begin{array}{l}\text { 1:30- } \\
\text { 2:00 }\end{array}$ & Kim & $\begin{array}{c}\text { Family mealtime } \\
\text { - } \text { Research } \\
\text { - } \\
\text { Strategies }\end{array}$ \\
\hline $\begin{array}{l}\text { 2:00- } \\
2: 30\end{array}$ & Earl Grey & Understanding Behavior Change \\
\hline $2: 30$ & $\begin{array}{l}\text { Elaine } \\
\text { Eric }\end{array}$ & $\begin{array}{l}\text { Wrap Up/Q\&A } \\
\text { Eric’s “send away messages } \\
\text { Parents write note to campers (reinforce trying new things, etc.) }\end{array}$ \\
\hline
\end{tabular}




\section{Camp NEW You for Parents \\ Sunday, July 26, 2008 \\ “Creating your family's solutions for a healthier environment" \\ 9:00-10:00 am Towers JB Lounge}

Learning Objectives:

1. To identify review resources parents have in their "Family Toolbox"

2. To make SMART goals for personal, home environment, and family fun/fitness

3. To gain skills in planning a Family Meeting

Materials:

- BodyWorks family toolkit

- PowerPoint

- Family Toolbox activity

- Goalsetting forms

- Family Mealtime handout

- Barriers/Solutions to Physical Activity brainstorming handout

- $\quad$ Flipchart \& markers

Outline:

\begin{tabular}{|c|c|c|}
\hline Time & $\begin{array}{l}\text { Lead } \\
\text { Presenter }\end{array}$ & Topic/Activity \\
\hline $\begin{array}{l}9: 00- \\
9: 15\end{array}$ & Elaine & $\begin{array}{l}\text { Session Introduction (PowerPoint) } \\
\text { Family Toolbox - pair up and identify “things” you have gained from } \\
\text { CNY that are in your toolbox to improve your family's health and } \\
\text { environment }\end{array}$ \\
\hline $\begin{array}{l}9: 15- \\
9: 30\end{array}$ & & $\begin{array}{l}\text { Goal Setting - } \\
\text { - } \quad \text { SMART goals } \\
\text { - } \quad \text { Demonstrate how to break large goals into smaller ones }\end{array}$ \\
\hline $\begin{array}{l}9: 30- \\
9: 40\end{array}$ & & $\begin{array}{l}\text { Family Meetings - } \\
\text { Tips } \\
\text { Agenda Examples }\end{array}$ \\
\hline $\begin{array}{l}9: 40- \\
9: 45\end{array}$ & & $\begin{array}{l}\text { Wrap Up - Parent's To Do List } \\
\text { - } \text { Focus on the positives } \\
\text { - } \text { Eye on the goal - health } \\
\text { - Open communication } \\
\text { - Call a family meeting } \\
\text { - Set weekly SMART goals with your child } \\
\text { Stay in touch }\end{array}$ \\
\hline $\begin{array}{l}9: 45- \\
10: 00\end{array}$ & Dr. Neal & $\begin{array}{l}\text { Doc Talk - Your Child's Health Report } \\
\text { Q\&A }\end{array}$ \\
\hline
\end{tabular}




\begin{abstract}
Vita
Kimberly N. Fisher

Current: 126 Orchard Crossing Morgantown, WV 26505

Phone: (304)-593-1112 Email: kfishe15@mix.wvu.edu

Permanent: PO Box 453 Gallipolis Ferry, WV 25515
\end{abstract}

\title{
EDUCATION:
}

West Virginia University; Morgantown, WV

Estimated Graduation Date: May 2009

Davis College of Agriculture, Forestry, \& Consumer Sciences

Human Nutrition \& Foods, Master of Science

Research: Effect of Home Environment on the Home Food Environment of Overweight

Adolescents in West Virginia

Research Supervisor: Dr. Cindy Fitch RD, PhD.

Marshall University; Huntington, WV

College of Health Professions

Dietetics, Bachelor of Science

Cumulative GPA: 3.23/4.0

\section{OBJECTIVE:}

To obtain a position as a Registered Dietitian that will utilize skills gained during my Didactic Master's and Internship program, while continuing to challenge my knowledge base and problem-solving abilities.

\section{Dietetic Internship:}

West Virginia University Morgantown, WV August 2007-present

- Foodservice experience within university related programs.

- Clinical experience including: assessing the needs and making recommendations for patients with various conditions such as renal insufficiency, diabetes, COPD, stroke, gastrointestinal disorders, and those in need of nutrition support

- Community nutrition experience with 4-H, WIC, child nutrition sites, and WVU Extension services.

- Experience in sports nutrition with university athletic teams and exercise physiologists.

Work Experience:

Famous Dave's

Barboursville, WV

Sept 2006-Aug 2007

Server/Hostess

- Assisted customers with seating preferences, menu choices.

- Worked as a team member with approximately 30 servers.

- Provided excellent customer service.

- Organized seating for restaurant with $200+$ seating capacity. 


\section{Sales Associate/ Sales Support Staff}

- Assisted clients with merchandise purchases, handled money.

- Provided excellent customer service.

- Stocked storeroom floor, kept stock room at merchandise flow standards.

Student Tutor Point Pleasant, WV Jan 2001- May 2002

- Tutored children aged 5-6 years in math and reading comprehension for grant funded program in Mason County, West Virginia.

\section{ORGANIZATIONS:}

- American Dietetic Association, Member Sept 2006present

- WVU Graduate Student Dietetic Association

o Member

o Officer, secretary

- Marshall University Student Dietetic Association

o Member

Oct 2005- May 2007

o President

Oct 2005- May 2006

\section{Computer Skills}

- Proficient in Windows, Microsoft Office, e-mail services, nutrition software Food Processor, and various internet browsers.

\section{Awards and Accomplishments}

- West Virginia Promise Scholarship recipient

Aug 2003May 2007

- Marshall University

o Presidential Scholarship recipient

o Dean's List

Aug 2003- May 2004

January 2006

\section{Professional Conferences}

- West Virginia Dietetic Association Annual Conference

April 2006 